\title{
Long Term Effects of Inorganic Fertilizers and Organic Amendments on Ammonification and Nitrification Activity of Soils under Cotton-Wheat Cropping System
}

\author{
Nisha Verma*, Suman Chaudhary and Sneh Goyal
}

Department of Microbiology, CCS Haryana Agricultural University, Hisar, Haryana, India

*Corresponding author

\begin{abstract}
A B S T R A C T
\section{Key words}

Arginine ammonification,

Nitrification activity,

Organic manures, Soil

chemical properties,

Vermicompost and

inorganic fertilizers

Article Info

Accepted:

07 March 2018

Available Online:

10 April 2018

The present investigation was carried out to study the effects of long-term application of inorganic fertilizers and organic amendments on soil organic matter level, soil biological properties and plant nutrient reserves. The continuous application of organic amendments for the last ten years under cotton-wheat cropping system at CCS H.A.U, Hisar had beneficial effects on soil chemical, arginine ammonification and nitrification activity as compared to application of chemical fertilizers. The soil $\mathrm{pH}$ ranged from 7.02 to 7.60. The electrical conductivity (EC) of soils increased from 0.24 to $0.40 \mathrm{dS} / \mathrm{m}$. The organic carbon increased from 0.359 to $0.689 \%$ with application of phosphor-vermicompost $+\mathrm{N}$ through organic source. Total P (Phosphorus) varied from 80.2 to 179.3 and available $\mathrm{P}$ from 20.9 to $37 \mathrm{mg} / \mathrm{kg}$ soil with the application of phosphovermicompost $+\mathrm{N}$ through organic source. Arginine ammonification activity ranged from 0.52 to $1.02 \mu \mathrm{g} \mathrm{NH}_{4}{ }^{+}-\mathrm{N} / \mathrm{g}$ soil/h and nitrification from 21.2 to $84.0 \mu \mathrm{g} \mathrm{NO}_{3}{ }^{-} \mathrm{N} / \mathrm{g} /$ day and were found highest in treatments with $75 \%$ RDN through vermicompost + Azotobacter $+\mathrm{P}$ requirement through rock phosphate and were lowest with inorganic fertilizers.
\end{abstract}

\section{Introduction}

There is increasing concern on long-term soil fertility and impact on environmental quality due to use of chemical fertilizers. The long term use of chemical fertilizers damages the soil physical properties and cause environmental pollution (Lal, 1998). No doubt the use of inorganic fertilizers increases the crop yield dramatically for a period, but without a good management there is rapid degradation of soil (Miller, 1998). There is need to develop a management system that permits sustained and hopefully improved level of agricultural output. These management systems should regenerate rather than deplete our soil resource. Integrated plant nutrient management system is one of the alternatives to conventional production system currently being advocated. Integrated plant nutrient management system is characterized by reduced input of chemical fertilizers and combined use of inorganic fertilizers and organic manures. The complementary use of chemical fertilizers, biofertilizers, organic manures and crop residues can ensure nutrient supply and long-term soil productivity. The benefits of balanced use of chemical fertilizers 
and organic manures have been increasingly emphasized (Oberson et al., 1996). Organic agriculture is another important alternative to conventional farming system using chemical fertilizers and pesticides. Organic agriculture is a production system which excludes the use of man-made chemicals (Dinesh et al., 2010). Food and environmental safety are often cited reasons towards adoption of organic farming. Organic farming relies on crop rotation, organic manures, green manures and off farm organic wastes to maintain soil productivity and to supply plant nutrients. Organic farming does not imply the simple replacement of synthetic fertilizers and other chemical inputs, instead it envisages comprehensive management to improve the health and productivity of soil (Stockdale et al., 2001). The use of organic soil amendments has been associated with desirable soil properties including increased water holding capacity, cation exchange capacity and lower bulk density and can foster beneficial microorganisms (Bulluck et al., 2002). Organic amendments also improve soil chemical properties such as supply and retention of soil nutrients and can promote favourable enzyme reactions (Mahmood et al., 2017). Management systems that rely on organic inputs as plant nutrients have different dynamics of nutrient availability from that involving the use of chemical fertilizers. Understanding of soil microbial processes that liberate plant nutrients is especially important in soils receiving organic amendments as source of plant nutrients. Different management systems may result in changes in soil microbial community which may influence nutrient dynamics and plant growth. Microbial biomass is a relatively small component of soil organic matter, but is a major determinant in nutrient cycling and organic matter stabilization. Measurement of soil microbial activities are important for ascertaining the functioning of soil ecosystem. Due to its dynamic nature, it responds quickly to changes in soil management as compared to soil organic matter level. The present study was conducted to examine the effect of organic, integrated and conventional farming systems on soil microbial properties.

\section{Materials and Methods}

\section{Experimental design and treatments}

The field experiment on cotton-wheat cropping system consisted of ten treatments along with a control in a randomized block design with four replications.

\section{Soil sampling and its preparations}

Soil samples were collected from ten different locations with different treatments fertilized with organic manures and combination of organic and inorganic nutrient sources from 0$15 \mathrm{~cm}$ layer in crop rotation systems from CCS HAU Hisar.

Soil samples amended with organic and inorganic manures from last ten years were drawn from research farm. The soil samples were sieved through $2 \mathrm{~mm}$ sieve and stored at $4^{\circ} \mathrm{C}$. The soil was moistened to 60 per cent water holding capacity (WHC) and incubated at $30^{\circ} \mathrm{C}$ for 10 days to permit uniform rewetting and to allow microbial activity to equalibriate after the initial disturbances. Subsamples of each soil were air-dried and ground for chemical analysis. Soil samples were analysed for arginine ammonification and nitrification activity.

\section{Analytical methods}

\section{Soil chemical properties}

Five gram soil was mixed with $12.5 \mathrm{ml}$ of distilled water. It was shaken for $30 \mathrm{~min}$ and $\mathrm{pH}$ of soil suspension was measured at room temperature with Systronics $331 \mathrm{pH}$ meter and 
Electrical Conductivity (EC) was measured with Naina electrical conductivity meter. The organic $\mathrm{C}$ in soil samples was determined by method of Kalembassa and Jenkinson (1973). The total P content in the digest was estimated on flame photometer by direct feeding. Available Phosphorus in soil samples was determined by method given by Olsen et al., (1954).

Arginine ammonificaiton and nitrification activity

Arginine ammonification and nitrification activity were determined by the method described by Kandeler (1995) and Beck (1979) respectively.

\section{Results and Discussion}

\section{Soil chemical properties}

The chemical properties of soil such as $\mathrm{pH}$, $\mathrm{EC}$, organic $\mathrm{C}$, total $\mathrm{P}$ and available $\mathrm{P}$ are influenced by various short and long term crop management practices such as crop rotations, organic manuring and chemical fertilizers.

Soil chemical analysis in cotton-wheat cropping system at CCS Haryana Agricultural University, Hisar, after ten years of application of organic fertilizers has been presented in Table 1. The soil $\mathrm{pH}$ ranged from 7.02 to 7.60 . The electrical conductivity (EC) of soils increased from 0.24 to $0.40 \mathrm{dS} / \mathrm{m}$. No significant difference in $\mathrm{pH}$ and $\mathrm{EC}$ of soils receiving different organic amendments was observed as compared to inorganic manures. Organic carbon increased from 0.359 to $0.689 \%$ with application of phosphorvermicompost $+\mathrm{N}$ through organic source. Organic C was $0.3 \%$ higher in soil receiving phospho vermicompost $+\mathrm{N}$ through organic source than in soil receiving RDN through $1 / 3$ FYM $+1 / 3$ Vermicompost $+1 / 3$ Neem. Total $\mathrm{P}$ increased from 80.2 to 179.3 and available $\mathrm{P}$ from 20.9 to $37 \mathrm{mg} / \mathrm{kg}$ soil with the application of phosphovermicompost $+\mathrm{N}$ through organic source. Naidu et al., (2009) studied the effect of organic and inorganic sources of nutrients on nutrient uptake and residual fertility of soil. The soil of experimental field was clayey in texture with $\mathrm{pH}$ of 7.4 , EC of $0.38 \mathrm{dSm}^{-1}$ and organic carbon of $0.572 \%$. The combined use of organics (farmyard manure, vermicompost, biofertilizers, panchagavya) along with the inorganic fertilizers increased nutrient use efficiency, apparent nutrient recovery and the available nutrient status of the soil. Integrated use of organic manures along with chemical fertilizers not only produced highest and sustainable crop yields but also enhanced the efficiency of added fertilizers as well as fertility status of the soil. Leite et al., (2009) found that soil organic carbon was higher in the organic management than in the conventional managed fields.

The soil under organic agricultural system had higher microbial activity and biomass but lower bulk density than the conventional agricultural system. Bulluck et al., (2002) reported higher level of $\mathrm{P}$ in soil with application of organic manures compared to synthetic soil fertility amendments and also found that $\mathrm{K}$ concentration in soils amended with organic amendments increased by a factor of three as compared to soils with synthetic fertility amendments, whereas the $\mathrm{K}$ concentrations decreased over time in soils with synthetic fertilizers. Mahmood et al., (2017) studied the effects of organic and inorganic manures on maize and their residual impact on soil physico-chemical properties Results showed that growth and yield of maize were substantially improved by fertilizer application alongside organic manures whereas soil total organic $\mathrm{C}$ and total $\mathrm{N}, \mathrm{P}, \mathrm{K}$ contents increased when inorganic fertilizers were applied alone or in combined with organic manures. 
Table.1 Effect of different organic and inorganic amendments on soil chemical properties in cotton-wheat rotation system at CCS H.A.U, Hisar

\begin{tabular}{|c|c|c|c|c|c|}
\hline Treatments & $\begin{array}{c}\text { pH } \\
(1: 2.5) \\
\text { ratio }\end{array}$ & $\begin{array}{c}\mathrm{EC} \\
\mathrm{dS} / \mathrm{m}\end{array}$ & $\begin{array}{l}\text { Organic } \\
\text { C } \\
(\%)\end{array}$ & $\begin{array}{l}\text { Total P } \\
\text { (mg/kg } \\
\text { soil) }\end{array}$ & $\begin{array}{l}\text { Available } \\
\text { P (mg/kg } \\
\text { soil) }\end{array}$ \\
\hline Absolute control (No fertilizer) & 7.02 & 0.24 & 0.359 & 80.2 & 20.9 \\
\hline Check (RDF through chemical fertilizer) & 7.36 & 0.29 & 0.412 & 108.7 & 24.2 \\
\hline RDN through FYM & 7.31 & 0.32 & 0.570 & 130.6 & 23.9 \\
\hline RDN through vermi-compost & 7.34 & 0.34 & 0.683 & 120.3 & 23.8 \\
\hline RDN through Neem cake & 7.46 & 0.35 & 0.583 & 125.0 & 31.5 \\
\hline $\begin{array}{l}\text { RDN through } 1 / 3 \text { FYM }+1 / 3 \text { vermi- } \\
\text { compost }+1 / 3 \text { Neem }\end{array}$ & 7.50 & 0.38 & 0.687 & 150.8 & 35.9 \\
\hline $\begin{array}{l}\text { Phospho-compost }+\mathrm{N} \text { through organic } \\
\text { source }\end{array}$ & 7.52 & 0.36 & 0.675 & 175.6 & 36.0 \\
\hline $\begin{array}{l}\text { Phosphovermi-compost }+\mathrm{N} \text { through } \\
\text { organic source }\end{array}$ & 7.56 & 0.39 & 0.689 & 179.3 & 37.0 \\
\hline $\begin{array}{l}75 \% \text { RDN through vermicompost }+ \\
\text { Azotobacter }+\mathrm{P} \text { requirement through } \\
\text { rock phosphate }\end{array}$ & 7.50 & 0.37 & 0.606 & 163.6 & 35.0 \\
\hline $\begin{array}{l}\text { T6 + cowpea intercropping in cotton and } \\
\text { mustard intercropping in wheat }\end{array}$ & 7.60 & 0.40 & 0.610 & 157.3 & 35.3 \\
\hline C.D. & N.S & N.S & 0.015 & 1.37 & 1.58 \\
\hline
\end{tabular}

Fig.1 Arginine ammonification activity as affected by different nutrient management practices in cotton-wheat rotation system at CCS H.A.U., Hisar

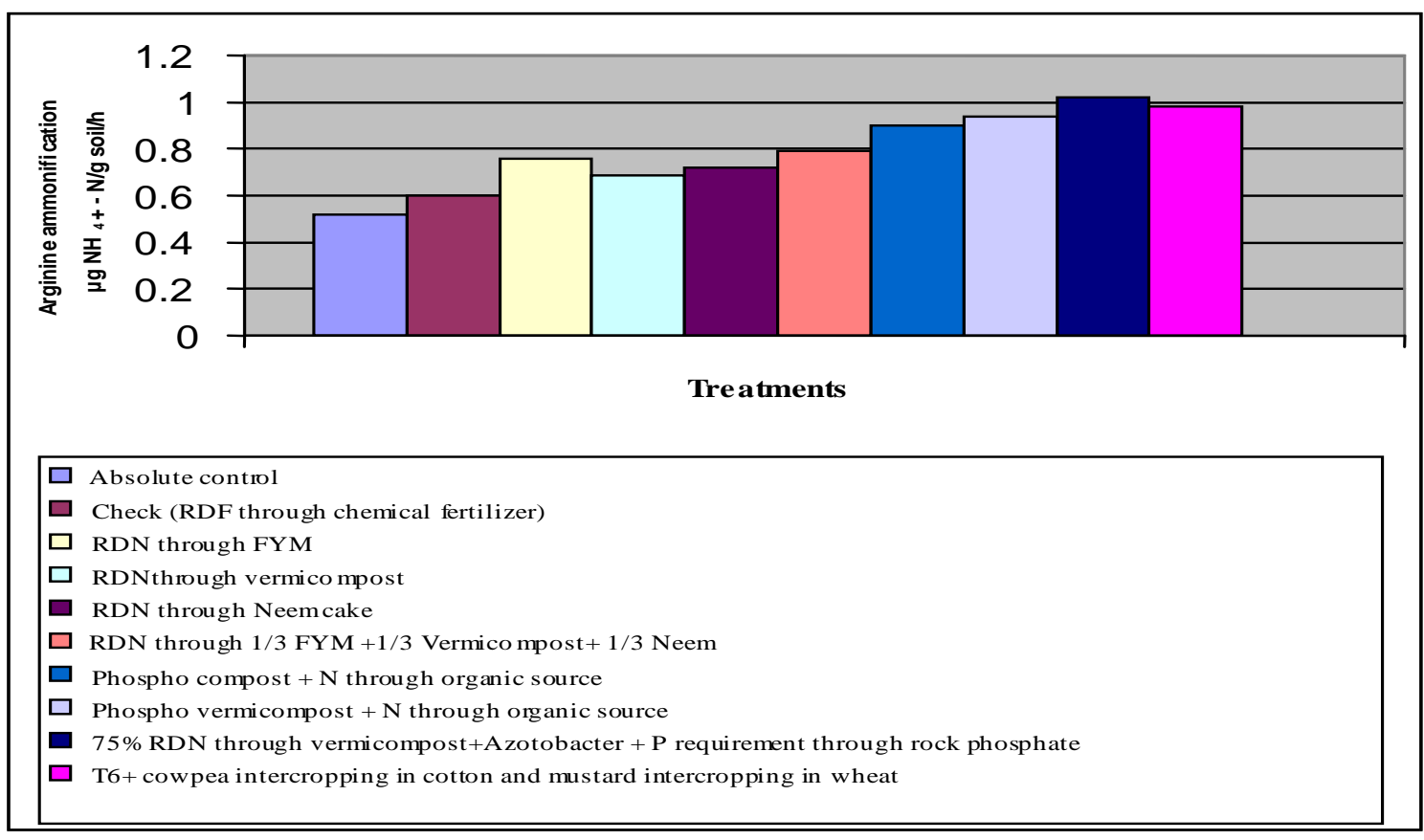


Fig.2 Nitrification activity as affected by different nutrient management practices in cottonwheat rotation system at CCS H.A.U, Hisar

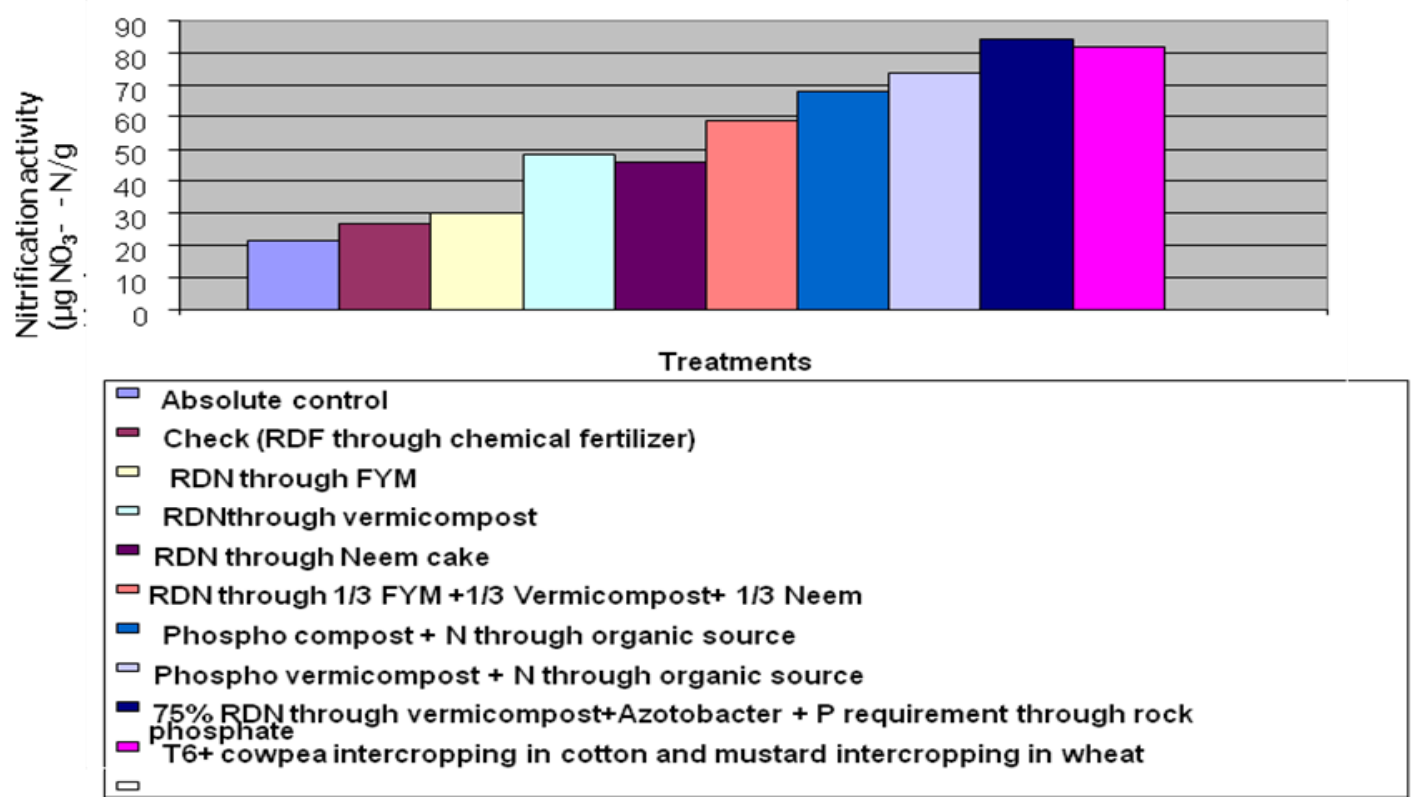

However, soil $\mathrm{pH}$ and soil bulk density decreased due to application of organic fertilizer and showed a negative correlation with grain yield. Further, a significant and positive correlation $\left(\mathrm{R}^{2}=0.52,0.91\right.$ and 0.55$)$ was observed among maize grain yield and available $\mathrm{N}, \mathrm{P}$ and $\mathrm{K}$ contents, respectively in the soil.

\section{Arginine ammonification activity}

Arginine ammonification is the first step in the mineralization of organic nitrogenous compounds in the soil. Arginine ammonification has been used as a index of ammonifying power of the soil.

Arginine ammonification ranged from 0.52 to $1.02 \mu \mathrm{g} \mathrm{NH}_{4}{ }^{+}-\mathrm{N} / \mathrm{g}$ soil/h under cotton-wheat rotation system at CCS H.A.U, Hisar (Figure 1). Arginine ammonification was higher in treatments receiving $75 \%$ RDN through vermicompost + Azotobacter $+\mathrm{P}$ requirement through rock phosphate followed by treatments with RDN through $1 / 3 \mathrm{FYM}+1 / 3$ Vermicompost $+1 / 3$ Neem cowpea intercropping in cotton and mustard intercropping in wheat $\left(0.98 \mu \mathrm{g} \mathrm{NH}{ }_{4}{ }^{+}-\mathrm{N} / \mathrm{g}\right.$ soil/h) and was lowest in treatment with only inorganic fertilizers. Arginine ammonification activity was $4.1 \%$ higher in soil receiving $75 \%$ RDN through vermicompost + Azotobacter $+\mathrm{P}$ requirement through rock phosphate than in soil receiving RDN through $1 / 3$ FYM $+1 / 3$ vermicompost $+1 / 3$ neem cowpea intercropping in cotton and mustard intercropping in wheat. Arginine ammonification was highest in soil with organic amendments in soil. Kaur et al., (2005) observed that arginine ammonification was higher in soils amended with organic manures with or without chemical fertilizers, indicating that more active microflora is associated with organic and integrated system using organic manures and chemical fertilizers together which is important for nutrient cycling.

\section{Nitrification activity}

Ammonium is produced during the decomposition of organic nitrogen 
compounds. Under natural habitats, ammonium is oxidized to nitrate and the process is called nitrification. Nitrification is carried out in two steps. In first step, ammonium is converted to nitrite and in second step nitrite is converted to nitrate.

Nitrification activity ranged from 21.2 to 0.84 $\mu \mathrm{g} \mathrm{NO}_{3}{ }^{+}-\mathrm{N} / \mathrm{g}$ soil/h under cotton-wheat rotation system at CCS H.A.U, Hisar (Figure 2). Nitrification activity was $2.5 \%$ higher in treatments with $75 \%$ RDN through vermicompost + Azotobacter $+\mathrm{P}$ requirement through rock phosphate followed by treatments with RDN through $1 / 3 \mathrm{FYM}+1 / 3$ vermicompost $+1 / 3$ neem cake + cowpea intercropping in cotton and mustard intercropping in wheat $\left(0.82 \mu \mathrm{g} \mathrm{NO}_{3}{ }^{+}-\mathrm{N} / \mathrm{g}\right.$ soil/h). Nitrification activity was higher in treatments receiving organic manures and a combination of organic manures and chemical fertilizers as compared to treatments receiving only inorganic manures.

\section{References}

Beck, T. 1979 Die Nitrifikation. In Boden (Sammelreferat). Z. Pflanzenernachr Bodenkd. 142: 299-309.

Bulluck, I. R., Brosius, M., Evanylo, G. K. and Ristaino, J. B. 2002 Organic and synthetic fertility amendments influences soil microbial physical and chemical properties on organic and conventional farms. Appl. Soil Ecol. 19: $147-160$.

Dinesh, R., Srinivasana, V., Hamzaa, S. and Manjushaa, A. 2010 Short-term incorporation of organic manures and biofertilizers influences biochemical and microbial characteristics of soils under an annual crop [Turmeric (Curcuma longa L.)]. Bioresour. Technol. 101: 4697-4702.

Kalembassa, S. J. and Jenkinson, D. S. 1973. A comparative study of titrimetric and gravimetric methods for determination of organic carbon in soil. J. Sci. Food Agric. 24: 1089-1090.

Kandeler, E. 1995. Arginine deaminase activity. In: Methods in Soil Biology. R. Schinner, R. Ohlinger, E. Kandeler and R. Margesin, R. (eds.) pp. 168-170. Springer-Verlag, Berlin.

Kaur, K., Kapoor, K. K. and Gupta, A. P. 2005 Impact of organic manures with and without mineral fertilizers on soil chemical and biological properties under tropical conditions. J. Plant Nutr. Soil Sci. 168: 117-122.

Lal, R. 1998 Soil quality and agricultural sustainability. In: Soil quality and agricultural sustainability. pp. 3-13. Lewis, Boca Raton.

Mahmood, F., Khan, I., Ashraf, U., Shahzad, T., Hussain, S., Shahid, M., Abid, Ullah, M. S. 2017. Effects of organic and inorganic manures on maize and their residual impact on soil physicochemical properties. J. Soil Sci. Plant Nutr. 17:22-32

Miller, P. F. 1998 Soil-land degradation : Interventions for sustaining civilization. In: Soil Quality and Agricultural Sustainability. R. Lal (ed.). pp. 13-32. Lewis, Boca Raton.

Naidu, D. K., Radder, B. M., Patil, P. L., Hebsur, N. S. and Alagundagi, S. C. 2009 Effect of integrated nutrient management on nutrient uptake and residual fertility of chilli $(\mathrm{Cv}$. byadgi dabbi) in a vertisol. Karnataka J. Agric. Sci. 22: 306-309.

Oberson, A., Besson, J. M., Maire, N. and Sticher, H.1996 Microbiological processes in soil organic phosphorus transformation in conventional and biological cropping systems. Biol. Fertil. Soils. 21: 138-148.

Olsen, S. R., Cole, C. V., Watanbe, F. S. and Dean, L. A. 1954 Estimation of available phosphorus in soil by 
extraction with sodium bicarbonate. U.S. Department of Agricultural Circular. 139.

Stockdale, E. A., Lampkin, N. H., Hovi, M., Keatinge, R., Lennartsson, E. K. M,
Macdonald, D.W., Padel, S., Tattersall, F. H., Wolfe, M. S. and Watson, C.A. 2001 Agronomic and environmental implications of organic farming systems. Adv. Agron. 70: 261- 325.

\section{How to cite this article:}

Nisha Verma, Suman Chaudhary and Sneh Goyal. 2018. Long Term Effects of Inorganic Fertilizers and Organic Amendments on Ammonification and Nitrification Activity of Soils under Cotton-Wheat Cropping System. Int.J.Curr.Microbiol.App.Sci. 7(04): 718-724. doi: https://doi.org/10.20546/ijcmas.2018.704.080 